\title{
Model Manajemen Pendidikan Life Skill pada Anak Berkebutuhan Khusus
}

\author{
Life Skill-Based Education Management Model for Children with Special Needs
}

\author{
Eka Prihatin, Imas Diana A \& Johar Permana \\ Universitas Pendidikan Indonesia, Bandung, Jawa Barat, Indonesia. \\ ekaprihatin@upi.edu
}

\begin{abstract}
Abstrak
Manajemen pendidikan Anak Berkebutuhan Khusus di berbagai belahan dunia, diorientasikan pada kecakapan hidup (life skill) untuk menghantarkan pada kemandirian. Dukungan Pemerintah dalam mencapai tujuan tersebut adalah memberikan kesempatan yang luas dalam pendidikan dan lapangan pekerjaan yang di payungi oleh Undang-Undang nomor 8 tahun 2016 tentang Penyandang Disabilitas menyatakan bahwa perusahaan swasta wajib mempekerjakan $1 \%$ penyandang disabilitas. Peluang ini menjadi sebuah tantangan dan tuntutan bagi pengelola pendidikan SMALB untuk mengsinkronkan antara kurikulum, proses pembelajaran dan standar kebutuhan DUDI. Salah satu sekolah yang responsif terhadap peluang tersebut adalah SMALB Subang, dimana lulusannya banyak terserap dunia kerja. Tujuan penelitian ini adalah analisis model manajemen pendidikan life skill pada anak berkebutuhan khusus yang berorientasi pada kemandirian dan keterserapan DUDI dengan jenis penelitian dan pengembangan (Research and Development) dari Borg \& Gall. Data dihimpun melalui studi dokumentasi, observasi dan wawancara dengan kepada sekolah, tenaga pendidik, perusahaan,orang tua siswaserta di validasi melalui Focus Group Discussion. Hasil penelitian menunjukkan bahwa manajemen pendidikan life skill, disusun melalui (1) perencanaan (planning) berdasarkan analysis and need assessment, (2) pelaksanaan (actuating) melalui ekstra kurikuler, program kemandirian, magang dan basic training di lembaga pelatihan dan/ DU/DI, (3) dan evaluasi (evaluating) oleh sekolah dan DU/ DI. Kesimpulan menunjukkan manajemen pendidikan life skill pada anak berkebutuhan khusus di SMALB Subang menempatkan sekolah sebagai sarana proses pembelajaran dan pemasaran lulusan dengan jalinan kerjasama antara sekolah, pemerintah, masyarakat dan DUDI.
\end{abstract}

Kata kunci: anak berkebutuhan khusus, kemandirian, life skill, manajemen pendidikan

\begin{abstract}
Abstrak
Management of education for Children with Special Needs in various parts of the world focuses on the life skills for developing independence. Government supports this by providing broad opportunities in education and employment which are covered by Law number 8 of 2016 about people with disabilities. It states that private companies must employ $1 \%$ of people with disabilities. This opportunity becomes a challenge and demand for SMALB education managers to synchronize curriculum, learning process and DUDI standard needs. One school that is responsive towards these opportunities is the SMALB Subang, where graduates are absorbed in the workforce. The purpose of this study is to analyze the life skill-based education management model for children with special needs that are oriented on independence and absorption of DUDI. This research and development model used Borg \& Gall's R\&D cycle. The data was collected through documentation, observation and interviews with school principals, educators, companies and parents, which then was validated through Focus Group Discussion. The results showed that the life skill-based education management could be compiled through (1) planning based on analysis and need assessment, (2) actuating through extra-curricular, independence programs, internships and basic training in training institutions and DU/DI, (3) and evaluation (evaluating) by schools and DU/DI. It can be concluded that life skill-based education management for children with special needs in SMALB Subang puts school as a meant of learning and graduates marketing in collaboration with government, community and DUDI.
\end{abstract}

Keywords: children with special needs, education management, independence, life skills 


\section{PENDAHULUAN}

Pada umumnya penyelenggaraan Pendidikan Khusus di Indonesia memiliki dua cara/ model yaitu layanan pendidikan segregasi dan layanan pendidikan terintegrasi atau terpadu. Pertama, model layanan pendidikan segregasi yaitu layanan pendidikan untuk ABK yang terpisah dengan anak normal pada umumnya. Di Indonesia bentuk sekolah segregasi ini berupa satuan pendidikan khusus atau Sekolah Luar Biasa sesuai dengan jenis kelainan peserta didik. Seperti SLB/A (untuk anak tunanetra), SLB/B (untuk anak tunarungu), SLB/C (untuk anak tunagrahita), SLB/D (untuk anak tunadaksa), SLB/E (untuk anak tunalaras), dan SLB/G (untuk anak tunaganda). Lebih lanjut, dalam pasal 4 PP No.72 Tahun 1991 bentuk satuan pendidikan luar biasa terdiri dari jenjang Sekolah Dasar Luar Biasa (SDLB) dengan lama pendidikan minimal enam tahun, Sekolah Lanjutan Tingkat Pertama Luar Biasa (SLTPLB) dengan lama pendidikan minimal tiga tahun dan Sekolah Menengah Luar Biasa (SMLB) dengan lama pendidikan minimal tiga tahun. Selain itu, pada pasal 6 PP No.72 Tahun 1991 juga dimungkinkan penyelenggaraaan Taman Kanak-kanak Luar Biasa (TKLB) dengan lama pendidikan satu sampai tiga tahun untuk meberikan layanan pendidikan prasekolah. Dengan demikian bahwa Taman Kanak-kanak Luar Biasa (TKLB), Sekolah Dasar Luar Biasa (SDLB), Sekolah Lanjutan Tingkat Pertama Luar Biasa (SLTPLB) dan Sekolah Menengah Luar Biasa (SMLB) terdiri dari berbagai jenis sesuai dengan kelainan masing-masing. Elaborasi hasil penelitian (Permana, 2018). Jenis pendidikan bagi siswa disabilitas adalah
Pendidikan Khusus yaitu pendidikan bagi peserta didik yang memiliki tingkat kesulitan dalam mengikuti proses pembelajaran karena kelainan fisik, emosional, mental, sosial dan/ atau memiliki potensi kecerdasan dan bakat istimewa (presiden R. Indonesia, 2003). Peserta didik berkelainan atau berkebutuhan khusus terdiri atas peserta didik yang: (1) tunanetra; (2) tunarungu; (3) tunawicara; (4) tunagrahita; (5) tunadaksa; (6) tunalaras; (7) berkesulitan belajar; (8) lamban belajar; (9) autis; (10) memiliki gangguan motorik; (11) menjadi korban penyalahgunaan narkotika, obat terlarang, dan zatadiktif lain; dan (12) 1. memiliki kelainan lain. Kebutuhan khusus diatas dapat juga berwujud gabungan dari 2 atau lebih jenis kelainan atau kebutuhan khusus yang dinamakan tunaganda. Sehingga layanan pendidikan yang diberikan merupakan layanan pendidikan khusus melalui satuan pendidikan khusus atau satuan pendidikan regular pada jalur formal dan nonformal, dengan kurikulum yang terdiri dari program umum, program kebutuhan khusus dan program kemandirian (Pendidikan, Kebudayaan, \& Indonesia, 2014).

Program umum dimaksudkan bahwa kurikulum yang diberikan disetarakan dengan kurikulum pendidikan regular, program kebutuhan khusus mencakup (1) pengembangan orientasi dan mobilitas, terutama bagi peserta didik tunanetra; (2) pengembangan komunikasi, persepsi, bunyi, dan irama, terutama bagi peserta didik tunarungu; (3) pengembangan binadiri, terutama bagi peserta didik tunagrahita; (4) pengembangan bina diri dan bina gerak, terutama bagi peserta didik tunadaksa; (5) 
pengembangan pribadi dan perilaku sosial, terutama bagi peserta didik tunalaras; dan (6) pengembangan interaksi, komunikasi, dan perilaku, terutama bagi peserta didik autis. Sedangkan program kemandirian, dikembangkan sebagai penguatan untuk bekal hidup mandiri, tidak tergantung pada orang lain dan bekal persiapan bekerja, dimana mencakup (1) teknologi informasi dan komputer; (2) akupressur; (3) elektronika; (4) otomotif; (5) pariwisata; (6) tata kecantikan; (7) tata boga; (8) tata busana; (9) komunikasi; (10) jurnalistik; (11) seni pertunjukan; dan (12) seni rupa dan kriya. (Pendidikan et al., 2014)

Program kemandirian merupakan pendidikan kecakapan hidup (life skill) yang diorientasikan untuk masuk pada dunia usaha dan dunia kerja, sehingga lulusan dari pendidikan khusus ini setara dengan pendidikan umum lainnya. Keberhasilan pendidikan kemandirian ini memerlukan perencanaan strategis yang inovatif dari peranan tenaga pendidik dan kependidikan serta dukungan pemerintah melalui kebijakan yang menjadi payung legalitas, dengan demikian keberadaan ABK dalam dunia usaha dan dunia kerja menjadi kewajiban bagi (1) Pemerintah, Pemerintah Daerah, Badan Usaha Milik Negara, dan Badan Usaha Milik Daerah mempekerjakan paling sedikit 2\% (dua persen) Penyandang Disabilitas dari jumlah pegawai atau pekerja. (2) Perusahaan swasta wajib mempekerjakan paling sedikit 1\% (satu persen) Penyandang Disabilitas dari jumlah pegawai atau pekerja (P. R. Indonesia, 2016)

Kebijakan di atas menjadi peluang yang sangat besar bagi pengelola pendidikan khusus untuk menghantar lulusannya masuk pada DUDI, sekaligus menjadi tantangan dalam penyelenggaraan layanan pendidikan yang memerlukan rencana strategis yang inovatif untuk membekali keterampilan yang sesuai dengan standar DUDI, menunjukkan bahwa program kemandirian sebagai life skill memerlukan penanganan yang spesial, komprehensif dan terintegrasi dalam kegiatan proses pembelajaran.

SMALB Subang merupakan salah satu sekolah khusus yang mengambil peluang tersebut, sehingga lulusannya banyak menempati dunia usaha maupun dunia kerja dan menjadi pilot projek yang dijadikan rujukan bagi sekolah khusus lainnya diseluruh Indonesia. Manajemen pendidikan yang diterapkan ditujukan untuk proses kemandirian sehingga peranan sekolah selain sebagai layanan pendidikan juga pemasar lulusannya. Keberhasilannya tidak terlepas dari kepemimpinan kepala sekolah dalam kecerdasan membaca peluang yang dianalisis dalam bentuk perencanaan strategis dalam setiap kegiatan sesuai dengan tuntutan dan stanmdar keterampilan yang dibutuhkan oleh DUDI melalui kolaborasi dengan pemerintah dan DUDI. Pelibatan DUDI dalam proses pembelajaran menjadi network dan membuka peluang kesempatan kerja bagi lulusan.

Program kemandirian sebagai pendidikan kecakapan hidup (life skill) merupakan pendidikan yang membekali peserta didik mengenai keterampilan untuk dapat hidup dalam kehidupan di masyarakat (Anwar, 2004; Build-it-yourself et al., n.d.; Ravindra Prajapati, Bosky Sharma, 2017; Tan, 2018; UNICEF, 2012; Vihar, 2011) mencakup kecakapan personal, sosial, akademik 
dan vokasional (Foster, 2002; Jaya et al., 2018; Munsi \& Guha, 2014; Specht, 2017; UNESCO \& UNICEF, 2013; Wood et al., 2012) untuk bekerja, berusaha dan/ atau hidup mandiri.

Kecakapan Personal (Personal Skill), yang terdiri dari: 1) Kecakapan Mengenal Diri (Self-Awarness Skill) meliputi kesadaran sebagai makhluk Tuhan, kesadaran akan eksistensi diri, dan kesadaran akan potensi diri. Kecakapan mengenal diri merupakan penghayatan diri sebagai makhluk Tuhan, makhluk sosial, bagian dari lingkungan, serta menyadari dan mensyukuri kelebihan dan kekurangan yang dimiliki, sekaligus meningkatkan diri agar bermanfaat bagi diri sendiri dan lingkungannya, yang diwujudkan dalam perilaku keseharian seperti beribadah sesuai agamanya, berlaku jujur, bekerja keras, disiplin, terpercaya, toleran terhadap sesama, suka menolong serta memelihara lingkungan.

2) Kecakapan Berpikir (Thinking Skill) Kecakapan berpikir merupakan kecakapan menggunakan pikiran atau rasio secara optimal, meliputi: a) Kecakapan Menggali dan Menemukan Informasi (Information Searching) Kecakapan menggali dan menemukan informasi memerlukan keterampilan dasar seperti membaca, menghitung, dan melakukan observasi. c) Kecakapan Mengambil Keputusan (Decision Making) Setelah informasi diolah menjadi suatu kesimpulan, tahap berikutnya adalah pengambilan keputusan. Dalam kehidupan sehari-hari, seseorang selalu dituntut untuk membuat keputusan betapun kecilnya keputusan tersebut. Karena itu peserta didik perlu belajar mengambil keputusan dan menangani resiko dari pengambilan keputusan tersebut. d) Kecakapan Memecahkan Masalah (Creative Problem Solving Skill) Pemecahan masalah yang baik tentu berdasarkan informasi yang cukup dan telah diolah. Pesera didik perlu belajar memecahkan masalah sesuai yang menuntut kemampuan berpikir rasional, berpikir kreatif, berpikir alternatif, berpikir sistem dan sebagainya. (Allen, 2014; Bruning, Schraw, Norby, \& Ronning, 2004; Dalgleish et al., 2007; Doyle, 2018; Ethic, 2017; Ireland, 2010; Kuliah \& S, 2007; Paul \& Elder, 2015; Skills et al., 2015; Specht, 2017; Vihar, 2011; WHO, 2016)

Kecakapan Sosial (Social Skill) disebut juga kecakapan antar-personal (inter-personal skill), yang terdiri atas: 1) Kecakapan Berkomunikasi dengan empati, sikap penuh pengertian, dan seni komunikasi yaitu kecakapan memilih kata dan kalimat yang mudah dimengerti oleh lawan bicara; 2) Kecakapan Bekerjasama (Collaboration Skill) Sebagai makhluk sosial, dalam kehidupan sehari-hari manusia akan selalu memerlukan dan bekerjasama dengan manusia lain yang menekankan saling pengertian, saling menghargai, dan saling membantu. (Bell, 2014; Coburn, 2008; Educator \& Cs, n.d.; Lai, DiCerbo, \& Foltz, 2005; Learn, 2015; Notari, Baumgartner, \& Herzog, 2014; Today, 2003)

Kecakapan Akademik (Academic Skill) disebut juga kecakapan intelektual atau kemampuan berpikir ilmiah dan merupakan pengembangan dari kecakapan berpikir rasional. Jika kecakapan berpikir rasional (thinking skill) masih bersifat umum, kecakapan akademik sudah mengarah kepada kecakapan yang bersifat keilmuan 
(akademik). Kecakapan akademik antara lain meliputi kecakapan mengidentifikasi variabel, menghubungkan variabel dengan fenomena tertentu, merumuskan hipotesis, dan merancang serta melakukan penelitian. (Karbalaei, 2012; Kathy Turner (Oxford University), 2015; Klimova, 2011a, 2011b; "Learning and Academic Skills Handbook for MSc Students," n.d.; Mat Daud. Nor Shidrah Binti, 2012; Study, 2014; Toppin \& Chitsonga, 2016; Young, 1992; Zetriuslita, Ariawan, \& Nufus, 2016)

Kecakapan Vokasional atau Kejuruan (Vocational Skill) disebut juga kecakapan kejuruan, yaitu kecakapan yang dikaitkan dengan bidang pekerjaan tertentu yang terdapat di masyarakat. Kecakapan vokasional meliputi: 1) Kecakapan Vocasional Dasar (Basic Vocational Skill) yang termasuk kecakapan vokasional dasar antara lain: kecakapan melakukan gerak dasar, menggunakan alat sederhana, atau kecakapan membaca gambar. 2) Kecakapan Vocational Khusus (Occupational Skill) Kecakapan ini memiliki prinsip dasar menghasilkan barang atau jasa. Sebagai contoh, kecakapan memperbaiki mobil bagi yang menekuni bidang otomotif dan meracik bumbu bagi yang menekuni bidang tata boga. (Aaltonen, Isacsson, Laukia, \& Vanhanen-nuutinen, n.d.; Abdul Wahab, Mustapha, Ahmad, \& Mohd Jelas, 2014; Abdullah-Al-Mamun, 2012; “en-pedagogy-evaluating-vocationaltraining-programs.pdf.crdownload," n.d.; UNESCO, 2008)

Ciri pembelajaran pendidikan berbasis life skill diataranya: (1) Identifikasi kebutuhan; (2) Penyadaran untuk belajar bersama; (3) Belajar untuk mengembangkan diri, belajar, usaha mandiri; (4) Penguasaan kecakapan personal, sosial, vokasional, akademik, manajerial, kewirausahaan; (5) Pemberian pengalaman dalam pekerjaan; (6) Interaksi dengan ahli; (7) Penilaian kompetensi; (8) Pendampiangan teknis untuk bekerja. (Anwar, 2004)

SMALB Subang merespon pendidikan life skill dengan strategi: (1) Kegiatan magang di tempat-tempat kerja/ latihan yang dikelola oleh instruktur ahli yang dekat dengan sekolah seperti penempatan di tempat cuci steam untuk belajar keterampilan mencuci motor/ mobil, penempatan di matrial untuk belajar keterampilan mebel sederhana, penempatan di salon untuk belajar memotong rambut atau merias wajah dan penempatan di di sanggar seni untuk belajar seni suara/ vocal. (2) Kegiatan pembelajaran dan pembekalan keterampilan melalui kerjasama dengan perusahaan penyalur tenaga kerja seperti kerja sama dengan CV Citra Serasi yang mempunyai proyek pekerjaan Cleaning service di BRI Subang. Pada program ini, siswa dilatih di sekolah oleh bimbingan ahli dari perusahaan, kemudian mereka magang di BRI bekerja sebagai cleaning service. (3) Kegiatan pembelajaran dan pembekalan keterampilan melalui kerjasama dengan industri. Pada program ini, siswa magang di salah satu perusahaan industri yang bergerak di bidang wiring hernes yaitu PT Subang Autocomp Indonesia.

Pembelajaran life skill bagi siswa disabilitas latihan berulang-ulang sampai menjadikan kebiasaan dalam hidup dengan jenis keterampilan disesuaikan dengan bakat dan minat siswa tersebut. Cakupan bahan ajar minimal meliputi kemampuan menolong diri 
atau kegiatan hidup sehari-hari, keterampilan bersosialisasai atau bermasyarakat di lingkungan tempat tinggal dan keterampilan untuk bekerja. Sebaiknya keterampilan untuk bekerja dipilih salah satu jenis pekerjaan atau sub-pekerjaan, yang dapat dicapai kualitas ketuntasan hasil belajar oleh siswa disabilitas. Dengan berbekal vokasi tersebut siswa disabilitas dapat mengembangkan diri atau bekerja pada pihak lain dengan memperoleh pengakuan penghasilan layak. Tentu saja model pembelajaran keterampilan ini memerlukan sistem pengelolaan yang melibatkan berbagai pihak secara fungsional (orangtua siswa, sekolah, industri atau unit usaha dan pemerintah terkait serta masyarakat).

\section{METODOLOGI PENELITIAN}

Jenis penelitian ini adalah Research and Development (R\&D) yang sebagaimana menurut Sukmadinata (2006) didefinisikan sebagai penelitian yang ditujukan untuk menghasilkan produk baru atau menyempurnakan produk yang telah ada. Peneliti melakukan Research and Development (R\&D) pada model manajemen pendidikan life skill berbasis vokasional di Sekolah Luar Biasa dalam rangka mempersiapkan siswa disabilitas untuk siap bekerja. Adapun sekolah yang menjadi pillot project dalam penelitian ini adalah SMA-LB Negeri Subang dengan mitra kerja PT Subang Autocomp Indonesia. Penghimpunan data dalam penelitian ini didapatkan dari sumber informan, sumber dokumen dan peristiwa dan/atau informasi spesifik mengenai objek penelitian. Dalam rangka mendapatkan data dan/atau informasi dari sumber-sumber tersebut, penelitian melakukan studi dokumentasi, observasi dan wawancara mendalam dengan melibatkan praktisi pendidikan, pelaku usaha dan orang tua.

\section{HASIL DAN PEMBAHASAN}

\subsection{Profil Sekolah Luar Biasa (SLB) Negeri} Subang

Sekolah Luar Biasa (SLB) Negeri Subang berada di pusat Ibu Kota Kabupaten Subang yang berdiri sejak tahun 1999. Sekolah ini mudah diakses dari berbagai daerah karena posisi sekolah yang tidak terlalu jauh dari jalan utama kota. Aksesibilitas tentu menjadi salah satu daya Tarik masyarakat sekitar.

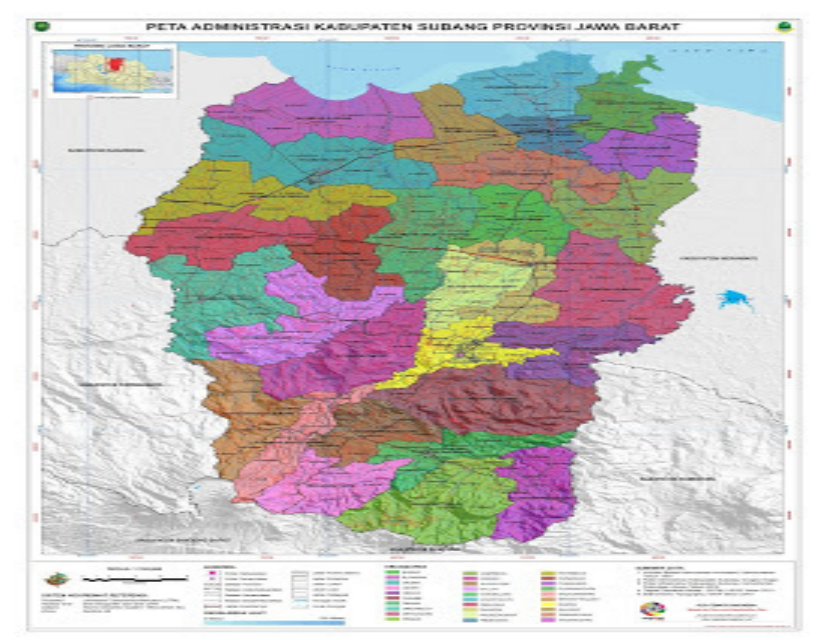

Gambar 1 Peta Wilayah Kabupaten Subang 
Sekolah Luar Biasa (SLB) Negeri Subang merupakan sekolah induk dari Sembilan sekolah yang ada di Kabupaten Subang gambar 1. Sekolah Luar Biasa (SLB) Negeri Subang memiliki jumlah pendidik sebanyak 31 orang dan tenaga kependidikan sebanyak 9 orang. Keberadaan sarana prasarana sekolah semakin baik dengan adanya dukungan dari pemerintah terhadap Sekolah Luar Biasa (SLB) Negeri Subang sangatlah besar. Selain itu, perhatian pemerintah terhadap kualitas pembelajaran juga diwujudkan dengan adanya kesejahteraan untuk para guru dan bentuk-bentuk perhatian lainnya.

Sekolah Luar Biasa (SLB) Negeri Subang diharapkan menjadi lembaga yang mampu memberikan pelayanan pendidikan yang baik, terutama dalam menyelenggarakan kualitas pembelajaran. Hal ini terutama menjadi tuntutan besar bagi sekolah untuk berinovasi dan berkreasi dalam meningkatkan kualitas Sekolah Luar Biasa (SLB) Negeri Subang.

\subsection{Gambaran Pelaksanaan pendidikan Life}

Skill pada siswa Disabilitas di Sekolah Luar Biasa (SLB) Negeri Subang

Aktivitas pembelajaran untuk siswa Sekolah Luar Biasa (SLB) Negeri Subang pada kelas X mendapatkan 44 jam pelajaran dan di kelas XI-XII adalah 46 jam pelajaran dengan program rutin yang ditekankan pada pembiasaan sekolah sebagai berikut:

1. Upacara bendera setiap hari Senin

2. Sholat Dhuhur berjama'ah setiap hari

3. Pengajian rutin setiap Hari Rabu sesudah sholat Dhuhur berjama'ah

4. Sholat Dhuha dan pengajian singkat untuk peserta didik setiap hari Kamis pagi
5. Senam kebugaran setiap Hari Jum'at pagi

6. Kegiatan jelajah alam (Pramuka) setiap Hari Sabtu

7. Ekstra pudding (makanan tambahan) setiap 2 minggu sekali untuk peserta didik

8. Gemar menabung setiap hari

9. Piket kelas

10. Berdoa bersama sebelum belajar

11. Budaya memberi salam antara guru dan peserta didik

12. Budaya hadir ke sekolah setiap hari

13. Budaya menebar senyum ramah di sekolah

SMALB Negeri Subang mengenalkan dan memberikan beragam latihan keterampilan bagi anak berkebutuhan khusus. Latihan keterampilan tata boga, tata busana, tata rias, perawatan rambut, perawatan tanaman, perawatan kendaraan, pertukangan, dan sebagainya. Tidak saja dilatih untuk terampil, tetapi juga tangguh dan bertanggung jawab, karena nilai-nilai sebagai calon pekerja dan calon pengusaha harus ditanamkan sejak dini. Melalui kerja keras, disiplin, tanggung jawab, teliti, dan ulet. Ketangguhan pada diri anak berkebutuhan khusus sangat diperlukan saat mereka harus bekerja. Semua dipersiapkan agar mereka mampu memasuki dunia kerja.

Dalam pengelolaan tenaga pendidik, Sekolah Luar Biasa (SLB) Negeri Subang memiliki tenaga pendidik dan kependidikan pada satuan pendidikan SDLB, SMPLB, dan SMALB. Jumlah keseluruhan tenaga pendidik adalah 31 dan tenaga kependidikan 9 orang pada tahun ajaran 2016/2017. Seluruh tenaga pendidik dan kependidikan terlibat penuh untuk mempersiapkan peserta 
didik yang mandiri. Kegiatan yang dilakukan tenaga pendidik dan kependidikan adalah berikut ini. (a) Mempersiapkan ilmu yang sesuai dengan bakat dan minat peserta didik. (b) Memberikan latihan-latihan secara berkelanjutan dari hal-hal yang sederhana, kemudian latihan-latihan yang lebih rumit; (c) Memotivasi peserta didik dalam setiap aktivitas pembelajaran; (d) Belajar bersama narasumber lain untuk melengkapi ilmu-ilmu yang diperlukan

Pengelolaan dalam sarana dan prasarana sekolah menjadi pendukung kegiatan latihanlatihan keterampilan siswa disabilitas. Beberapa fasilitas yang dimiliki SLB Negeri Subang berkaitan kegiatan keterampilan adalah berikut ini. (a) Ruang Keterampilan Menjahit; (b) Salon "Cantik"; (c) Kantin Sekolah; (d) Laboratorium Tata Boga; (e) Kebun Sekolah; (f) kolam Ikan; (g) Area Cuci Motor; (h) Area Pertukangan; (i) Area Pameran; (j) Bank Mini. Sarana dan Prasarana Pendukung lainnya adalah seperti mushola, perpustakaan, ruang UKS, ruang terapy bicara, ruang aula, ruang kelas, ruang tamu, ruang guru, ruang TU, ruang kepala sekolah, resource center, arena tunggu orang tua, areabermain, lapangan olahraga, Pos Satpam, gudang, dan kamar mandi. Seluruh ruangan berfungsi secara optimal untuk mendukung pembelajaran. Keadaan ini juga memberikan dukungan kenyamanan bagi seluruh warga sekolah yang memanfaatkan setiap area.

Pengelolaan pembiayaan pendidikan; SLB Negeri Subang sebagi sekolah negeri memiliki beberapa sumber daya yang menjadi pendukung kegiatan keterampilan di sekolah yaitu (a) Dana rutin pemerintah; (b) Dana subsidi warga sekolah; (c) Dana bantuan dari luar pemerintah. Masyarakat memberikan dukungan penuh terhadap seluruh kegiatan di SLB Negeri Subang. Bentuk dukungan masyarakat adalah: (a) Partisipasi aktif dalam setiap event kegiatan-kegiatan sekolah; (b) Publikasi positif pada masyarakat lua; (c) Adanya promosi tidak langsung terhadap masyarakat berkaitan dengan prestasi sekolah. Juga dari Dunia Usaha/Industri dan Pemerintah, di mana secara bertahap sekolah selalu mengadakan kegiatan pentas seni dan pameran. Kegiatan ini dimaksudkan menjadi daya tarik bagi dunia usaha/dunia industri serta pemerintah terkait untuk hadir melihat bukti nyata keberadaan anak berkebutuhan khusus. Event ini selalu menjadi sentuhan awal untuk membuka jaringan-jaringan kerjasama dalam beragam bentuk. Sehingga kehadiran anak berkebutuhan khusus dapat diterima

\subsection{Manajemen Peserta Didik dalam Pendidikan Life Skill pada Siswa Disabilitas}

Manajemen "Ganas Madu" menjadi ciri khas Sekolah Luar Biasa (SLB) Negeri Subang. Sesuai filosofi ganas madu yang terpilih sebagai nanas istimewa, para siswa disabilitasadalah anak-anak istimewa yang menjadi aset Kabupaten Subang. Dengan kata lain mereka memiliki potensi untuk mandiri dan unggul di Kabupaten Subang. (1) Mata Buah Bagai Jaring Mengikat Mata Buah Nanas Bagai Jaring-Jaring dalam arti Mengikat adalah usaha keras dan terencana yang dilakukan sekolah melalui beragam latihan keterampilan. Latihan yang diberikan guru-guru terpilih. Semua latihan keterampilan membekali diri anak berkebutuhan khusus menjadi terampil; (2) 
Daun Panjang Berujung Tajam Dunia Usaha dan Dunia Industri serta Instansi, artinya Pemerintah memiliki potensi membantu anak berkebutuhan khusus. Mereka hadir memberi peluang. Namun, menghadirkan support mereka membutuhkan kerja keras. Daun panjang berujung tajam menjadi cerminan usaha keras sekolah untuk mencari dukungan dari dunia usaha dan industri, serta instansi pemerintah; (3) Kulit Tebal yang Kokoh, dalam arti Kulit tebal yang kokoh adalah karakter anak berkebutuhan khusus. Tangguh dan kuat, tertanam nilai-nilai positif yang terbentuk dari hasil latihan dan pendidikan di sekolah. Peserta didik SMALB dipersiapkan sejak awal untuk mengikuti program pembelajaran keterampilan (Program kemandirian pada Kurikulum 2013) dengan muatan jam pembelajaran yang lebih banyak.

Hal-hal yang dipersiapkan adalah berikut ini. (a) Seluruh peserta didik SMALB dikenalkan pada beberapa bidang keterampilan; (b) Setiap peserta didik diberikan informasi tentang manfaat jangka panjang terhadap penguasaan keterampilan; (c) Setiap peserta didik diberikan motivasi untuk menyenangi beragam tugas keterampilan; (d) Penanaman nilai-nilai kerja sama, kerja keras, ketekunan, kerapihan, disiplin, dan tanggung jawab terhadap semua tugas-tugas; (e) Tenaga pendidik diwajibkan menyiapkan dokumen utama dan pendukung. Dokumen yang digunakan sebagai bahan rujukan untuk merekomendasikan kemampuan peserta didik.

\subsection{Sistem Pasar kerja Siswa Disabilitas} di Sekolah Luar Biasa (SLB) Negeri Subang

Sekolah mengadakan kerjasama dengan dunia usaha/industry. (1) Unit Usaha Kecil sebagai
Mitra kerja dari masyarakat sekitar, hal ini sangat membantu Sekolah Luar Biasa (SLB) Negeri Subang dalam menyalurkan potensi siswa untuk berlatih keterampilan secara mandiri dalam program magang. Usaha kecil yang dikelola masyarakat dan telah menjadi mitra kerja adalah: (a) Salon Kecantikan Fetty pimpinan ibu Fatiawati; (b) PD. Mulya Tani pimpinan bapak Ade Nuryaman; (c) Rumah Makan Mulya Tani pimpinan ibu Romiatun; (d) Cuci Motor "Jago" Soklat pimpinan Bapak Duraksa. Unit usaha masyarakat ini sejakawal program sekolah telah memberikan kesempatan yang seluas-luasnya bagi peserta didik untuk berlatih magang. Fokus kegiatan yang telah dilakukan peserta didik adalah (a) Perawat rambut di Salon Kecantikan Fetty; (b) Menata material barang bangunan serta menghaluskan material kayu berbentuk pintu dan kusen pintu di PD. Mulya Tani; (c) Petugas kasir di Rumah Makan Mulya Tani.; (d) Pelayan makanan di Rumah Makan Mulya Tani; (e) Petugas di Cuci Motor "Jago" Soklat.

(2) Kerja sama denga Perusahaan besar. Perusahaan besar yang sudah memahami Undang-undang Nomor 8 Tahun 2016 tentang Disabilitas, akan mematuhi ketentuan tentang jumlah tenaga kerja disabilitas di setiap perusahaan negeri atau swasta, perusahaan-perusahaan yang diamksud di antaranya: Bank Rakyat Indonesia Cabang Subang melalui program Cleaning Service menerima peserta didik untuk magang di BRI selama satu bulan, PT. Subang Autocomp Indonesia (SUAI) merupakan industri besar yang bergerak di bidang manufacture wiring harness yang telah bekerja sama dengan SLB Negeri Subang dengan memberikan peluang magang bahkan sampai bekerja yang sangat 
baik untuk siswa disabilitas. Saat ini, siswa disabilitas yang menjalani proses magang di PT. SUAI telah mencapai jumlah 30 orang sejak bulan Februari 2016.

\section{SIMPULAN}

SMALB Subang memiliki visi "terdidik, terlatih, mandiri berdasarkan iman dan taqwa". Kemudian visi tersebut menjadi ruh dalam setiap agenda sekolah yang diuraikan dalam sebuah dokumen lengkap perencanaan (sekolah) menjadi tujuan, sasaran, strategi, kebijakan, program dan kegiatan pendidikan di sekolah pada periode tertentu. Kegiatan assessment ini menurut Kepala Sekolah SLB Negeri Subang setidaknya meliputi tiga hal yaitu menyerap aspirasi, melakukan koordinasi dan menangkap peluang baik secara internal maupun eksternal. Pertama, penyerapan aspirasi terlihat betul dalam assessment peserta didik yang menurut salah satu guru SLB Negeri Subang bahwa assessment ini dilakukan untuk mengetahui potensi dan bakat siswa yang mungkin dapat dikembangkan

Kurikulum yang digunakan oleh SMALB adalah Kurikulum 2013 yang berisi program umum, program kebutuhan khusus dan program kemandirian. program kemandirian pada kurikulum pendidikan khusus dikembangkan sebagai penguatan bagi siswa disabilitas untuk bekal hidup mandiri, tidak tergantung pada orang lain, dan untuk bekal persiapan bekerja. Adapun program pilihan kemandirian yang dapat diselenggarakan oleh sekolah terdiri dari (a) teknologi informasi dan komputer; (b) akupressur; (c) elektronika; (d) otomotif; (e) pariwisata; (f) tata kecantikan; (g) tata boga; (h) tata busana; komunikasi; (i) jurnalistik; (j) seni pertunjukan; dan (k) seni rupa dan kriya.

SMALB Negeri Subang yang menjadi pillot project memiliki program keterampilan tata boga, tata busana, tata kecantikan, bank mini, pertanian, dan pertukangan. Pembimbing pada setiap keterampilan disiapkan sekolah. Di sisi lain, melalui wawancara dengan guru SLB Negeri Subang bahwa dalam rangka mendukung program kemandirian tersebut, sekolah menyertakan guru dalam pelatihan keterampilan kecantikan, hantaran dan menjahit.

Program kemandirian yang dilakukan adalah (1) mendatangkan ahli dan kerjasama dengan Sekolah Menengah Kejuruan; (2) pelatihan keterampilan dasar (basic training) yaitu pembekalan keterampilan pada siswa disabilitas untuk mengikuti kegiatan magang di Dunia Usaha/ Industri. Sebelum melaksanakan kegiatan magang, peserta magang diikut sertakan dalam basic training yang merupakan pembekalan materi-materi untuk kegiatan magang sehingga mereka lebih siap mengikuti kegiatan magang tersebut; (3) Magang. Kegiatan magang diberlakukan pada siswa kelas XI untuk rentang waktu kurang lebih tiga bulan.

PT Subang Autocomp Indonesia, yang pada saat ini telah mempekerjakan $1 \%$ penyandang disabilitas dari jumlah karyawan keseluruhan $(80 \%$ tunarungu dan $20 \%$ tunagrahita ringan), melakukan tiga tahap penjajakan dalam mempekerjakan siswa disabilitas yaitu: Pertama, uji coba pekerja disabilitas dengan menempatkan mereka pada pekerjaan pada jenis pekerjaan supporting. Kedua tahap pengembangan di mana dilakukan penambahan jumlah 
penyandang disabilitas yang bekerja dan perluasan uji coba pekerjan ke pekerjaan produksi. Ketiga tahap penyempurnaan di mana penambahan jumlah penyandang disabilitas sampai mencapai 1\% dari jumlah karyawan dan perluasan area rekrutmen dari sekitar Kabupaten Subang.

\section{DAFTAR RUJUKAN}

Aaltonen, K., Isacsson, A., Laukia, J., \& Vanhanen-nuutinen, L. (n.d.). Practical skills, education and

development - Vocational education and training in Finland Sales of the publication.

Abdul Wahab, N., Mustapha, R., Ahmad, A. R., \& Mohd Jelas, Z. (2014). Vocational Education and Skills Training for Indigenous Community in Malaysia. Journal of Education and Practice, 5(11), 179-184.

Abdullah-Al-Mamun, M. (2012). The Soft Skills Education for the Vocational Graduate: Value as Work Readiness Skills. British Journal of Education, Society \& Behavioural Science, 2(4), 326-338. https://doi. org/10.9734/BJESBS/2012/1858

Allen, C. (2014). Creative Thinking for Senior Leaders: An essay on creative thinking for military professionals, $1-12$.

Anwar. (2004). Life Skills Education.

Bell, M. (2014). Face-to-Face Verbal Communication and Social Skills : The Link to Adolescent Learning.

Bruning, R. H., Schraw, G. J., Norby, M. M., \& Ronning, R. R. (2004). Problem solving and critical thinking, 162-192.

Build-it-yourself, H., Build-it-yourself, H., Game, Y., Build-it-your-, H., Game, O., Kk, O., ... Controllers, S. (n.d.). Content list.

Coburn, A. (2008). R Eview : C Ommunity E Ducation, L Ifelong L Earning and S Ocial I Nclusion, (62), $127-130$.

Dalgleish, T., Williams, J. M. G. ., Golden, A.-M. J., Perkins, N., Barrett, L. F., Barnard, P. J., ... Watkins, E. (2007). [ No Title ]. Journal of Experimental Psychology: General, 136(1), 23-42.

Doyle, A. (2018). Personal skills. The Balance. Retrieved from https://www.thebalancecareers.com/personalskills-list-2063763

Educator, A., \& Cs, F. (n.d.). A-Guide-to-Four-Cs.pdf.

en-pedagogy-evaluating-vocational-training-programs.pdf.crdownload. (n.d.).

Ethic, W. (2017). Personal Skills Exhibiting a passion for life and career.

Foster, M. (2002). Life Skills. Occupational Therapy and Physical Dysfunction.

Indonesia, presiden R. (2003). UU No.20 Tahun 2003 tentang Sistem Pendidikan Nasional.

Indonesia, P. R. (2016). UU No.8 Tahun 2016.

Ireland, N. (2010). Thinking Skills and Personal Capabilities in the Foundation Stage Promoting Thinking Skills and Personal Capabilities across the curriculum in the Foundation Stage.

Jaya, H., Haryoko, S., Saharuddin, Suhaeb, S., Sabran, \& Mantasia. (2018). Life Skills Education for Children with Special Needs in order to Facilitate Vocational Skills. Journal of Physics: Conference Series, 1028(1). https://doi.org/10.1088/1742-6596/1028/1/012078

Karbalaei, A. (2012). Critical thinking and academic achievement. Íkala, 17(2), 121-128. https://doi.org/10.1109/ CISIS. 2010.68

Kathy Turner (Oxford University). (2015). Essential Academic Skills 2Nd Edition. Aging, 7(11), 956-963. https:// doi.org/10.1017/CBO9781107415324.004

Klimova, B. F. (2011a). Assessment methods in the course on academic writing. Procedia - Social and Behavioral Sciences, 15, 2604-2608. https://doi.org/10.1016/j.sbspro.2011.04.154

Klimova, B. F. (2011b). Assessment methods in the course on academic writing. Procedia - Social and Behavioral Sciences, 15(May), 2604-2608. https://doi.org/10.1016/j.sbspro.2011.04.154

Kuliah, M., \& S, O. S. (2007). Kecakapan ( Life Hidup Skill ), (Ki 502).

Lai, E., DiCerbo, K., \& Foltz, P. (2005). Skills for Today. Executive Development, (June).

Learn, S. S. (2015). Skills for the 21, (May). 
Learning and Academic Skills Handbook for MSc Students. (n.d.).

Mat Daud. Nor Shidrah Binti. (2012). Developing Critical Thinking Skills in Tertiary Academic Writing Through the Use of an Instructional Rubric for Peer Evaluation, (July), 1-331. https://doi.org/10.1080/0014013 9.2012.718366

Munsi, K., \& Guha, D. (2014). Status of life skill education in teacher education curriculum of saarc countries : A comparative evaluation. Journal of Education and Social Policy, 1(1), 93-99.

Notari, M., Baumgartner, A., \& Herzog, W. (2014). Social skills as predictors of communication, performance and quality of collaboration in project-based learning. Journal of Computer Assisted Learning, 30(2), 132-147. https://doi.org/10.1111/jcal.12026

Paul, R., \& Elder, L. (2015). Office of the Vice-President for Learning Innovation and Registrar Introduction: understanding why creative and critical thinking skills are important. Retrieved from www. criticalthinking.org

Pendidikan, M., Kebudayaan, D. A. N., \& Indonesia, R. (2014). Kurikulum Pendidikan Khusus.

Permana, J. (2018). Manajemen Pendidikan Life Skill. Laporan Penelitian. https://doi.org/10.1016/j. palaeo.2007.10.013

Ravindra Prajapati, Bosky Sharma, D. S. (2017). Significance Of Life Skills Education. Contemporary Issues in Education Research - First Quarter, 10(1), 1-6. Retrieved from https://files.eric.ed.gov/fulltext/ EJ1126842.pdf

Skills, L., Initiative, C. E., Africa, N., Twelve, T., Life, C., \& Dimension, C. (2015). The Twelve Core Life Skills.

Specht, J. (2017). Personality development research. Personality Development Across the Lifespan, 3-6. https:// doi.org/10.1016/B978-0-12-804674-6.00001-6

Study, O. U. (2014). 301 Academic Skills Resource : Critical Thinking Defining critical thinking Critical reading, (2012), 1-4.

Tan, S. (2018). Life Skills Education: Teachers' Perceptions in Primary School Classrooms in Finland and Singapore.

Today, N. E. A. (2003). What We Know About Bullying, 2002-2003. https://doi.org/10.1177/0031721716671899

Toppin, I. N., \& Chitsonga, S. (2016). Critical Thinking Skills and Academic Maturity: Emerging Results from a Five-Year Quality Enhancement Plan (QEP) Study. Journal of Inquiry and Action in Education, 7(2), 81-93. https://doi.org/10.1016/S0266-8920(97)00003-9

UNESCO. (2008). Technology-based vocational skills training for marginalized girls and young women. Retrieved from http://unesdoc.unesco.org/images/0016/001626/162605e.pdf

UNESCO, \& UNICEF. (2013). Life Skills and Lifelong Learning.

UNICEF. (2012). Global Evaluation of Life Skills Education Programmes. Evaluation Office, (August), 177.

Vihar, P. (2011). Life Skills Education. Adolescence.

WHO. (2016). Skills for Health, 90. Retrieved from https://www.skillsplatform.org/organisation/skills-for-health/ courses/e-learning

Wood, J., Antonowicz, L., Clarke, D., Daniel, P., Grout-Smith, J., \& Tibbits, F. (2012). Global Life Skills Education Evaluation, (February).

Young, L. E. (1992). Thinking Skills : October, (June). https://doi.org/10.1177/019263659207654806

Zetriuslita, Ariawan, R., \& Nufus, H. (2016). Students ' Critical Thinking Ability : Description Based on Academic Level and Gender, 7(12), 154-164. 